\title{
Debt and Private Investment: Does the EU Suffer from a Debt Overhang?
}

\author{
Willem Vanlaer ${ }^{1} \cdot$ Mattia Picarelli $^{2} \cdot$ Wim Marneffe ${ }^{1}$
}

Accepted: 22 March 2021 /Published online: 13 May 2021

(C) The Author(s), under exclusive licence to Springer Science+Business Media, LLC, part of Springer Nature 2021, corrected publication 2021

\begin{abstract}
This paper exploits a panel of 28 European Union (EU) countries between 1995 and 2016 to analyze whether higher debt resulted in lower private investment - the so called debt overhang effect. We deal with the potential endogeneity between private investment and other macroeconomic determinants by applying an instrumental variable approach (GMM). Our results support the debt overhang hypothesis and indicate that this relationship only works through the public debt channel. In our baseline regression, a 10 percentage point increase in public debt reduced private investment by $€ 18.32$ billion, given the levels of private investment prevalent in 2016. By contrast, private debt does not appear to be a significant determinant of private investment. These results hold after controlling for a number of factors that might have caused public debt to increase and private investment to decrease. While our analysis focuses on the financial sector channel, we find no evidence that public debt tightens the credit constraints for private firms or worsens the public debt overhang. We also show that government bailouts of the financial sector, which could alleviate financial distress and boost credit provision, do not appear to be effective in mitigating the public debt overhang effect. Finally, we find evidence that the financial openness of a country does alleviate the negative impact of public debt on private investment. This might suggest that attracting foreign capital compensates for a contraction in the domestic pool of financial resources due to higher public debt levels.
\end{abstract}

Keywords Debt overhang $\cdot$ Private investment $\cdot$ Dynamic panel data

Willem Vanlaer

willem.vanlaer@uhasselt.be

1 Hasselt University, Faculty of Applied Economics, Martelarenlaan 42, BE-3500 Hasselt, Belgium

2 European Stability Mechanism, 6a Circuit de La Foire Internationale, L-1347 Luxembourg City, Luxembourg 


\section{Introduction}

Following the devastating economic crisis that the COVID-19 pandemic caused, the European economy appears to be emerging from one of the deepest recessions it has ever encountered. Governments, authorities, and banks have undertaken unprecedented measures to mitigate the economic impact of the pandemic. As a result, public and private sector borrowing rose markedly in 2020 and is projected to continue rising even more in 2021. Over the first three quarters of 2020, government debt in the euro area increased by a staggering $\$ 1.5$ trillion. This raised concerns that such a large amount of accumulated debt will weigh on successfully relaunching economic activity and keeping investment low, which is set to revive the debate on the negative effect debt could have on the economy (Reinhart and Rogoff 2010). Our paper tackles this research question by studying the impact of both public and private debt on private investment, since providing incentives for private investment will be imperative to kick-starting economic recovery following the COVID-19 related crisis.

Private investment in the EU dropped significantly when the Global Financial Crisis (GFC) erupted in 2007, and has failed to recover to pre-GFC levels ever since (Fig. 1). ${ }^{1}$ Between 2007 and 2013 real GDP dropped by $0.12 \%$ in the EU, $1.51 \%$ in the euro area, and $9.40 \%$ in the group of most indebted countries (Portugal, Ireland, Italy, Greece, and Spain - PIIGS). Similarly, private gross fixed capital formation (GFCF), expressed in constant prices, decreased by $13.73 \%$ in the EU, $15.58 \%$ in the euro area, and $21.62 \%$ in the PIIGS countries.

There is no consensus on the reason why private investment collapsed following the GFC. One potential explanation for this conundrum relies on the uncertainty surrounding future economic conditions due to excessive debt levels (Bricongne et al. 2020). ${ }^{2}$ While private investment plummeted, debt metrics surged. Between 2007 and 2013, the stock of public debt increased by $48.90 \%$ in the EU, by $54.84 \%$ in the euro area, and by $76.69 \%$ in the PIIGS countries. Correspondingly, private debt increased by $6.85 \%$ in the EU, by $6.90 \%$ in the euro area, and by $0.47 \%$ in the PIIGS countries.

Private investment has generally been low during periods of high public debt levels (left-hand side chart of Fig. 1). The picture is more mixed when private debt is taken into account (right-hand side chart of Fig. 1). The two variables co-vary between 1995 and 2006, but when the GFC erupted, private debt remained quite stable although at a high level, whereas private investment dropped significantly.

Private investment, both by corporations and households, is important for mainly three reasons. First and foremost, private GFCF makes up a relatively large share of GDP, ${ }^{3}$ and remains an important determinant of long-term growth (Khan and Reinhart 1990). Hence, large drops in investment result in lower or even negative GDP growth.

\footnotetext{
${ }^{1}$ See Appendix 1 for the country-specific paths.

2 Due to the rapid increase in government debt observed after 2007, a large strand of economic literature has been dedicated to estimating the effects of public sector borrowing on economic activity (Reinhart and Rogoff 2010). There is only limited research on what has driven the post-crisis drop in private investment. For example, the European Investment Bank (EIB) (2013) reported that the most critical factor driving this decline was uncertainty about the world economy after the GFC. Until this uncertainty dissipated, investors took a 'wait-and-see' approach and delayed large investments.

${ }^{3}$ In 2015, for example, private GFCF in the EU28 was $17.2 \%$ of GDP, $12 \%$ of which represented business investment and $5.2 \%$ household investment.
} 


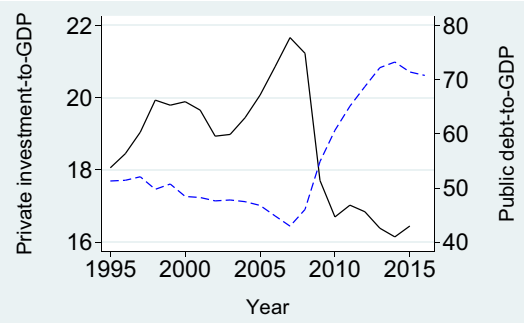

- Private investment-to-GDP - Public debt-to-GDP

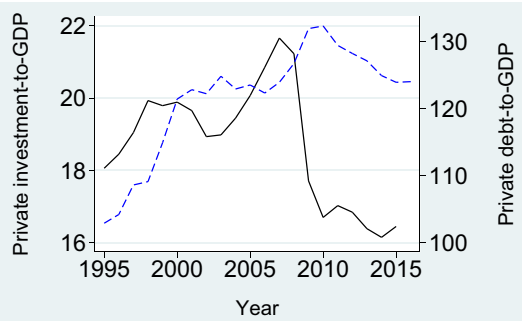

Private investment-to-GDP Private debt-to-GDP

Fig. 1 Private investment and debt as a percentage of GDP for the EU28, 1995-2016

Moreover, investment in $R \& D$ results in technological progress that, in turn, yields productivity increases (Krugman and Mankiw 1994). Productivity increases might also emanate from private investment being helpful in reallocating resources from less productive sectors to more productive ones (Banerjee and Hofmann 2018). Second, from a policy perspective, high levels of investment in targeted sectors (such as renewable energy and artificial intelligence) are required to ensure EU competitiveness in specific areas, with the ultimate goal of sustaining high income levels. Third, to support the economic recovery from the COVID-19 related crisis, it is essential to revive private investment. The idea is not only to provide a short-term economic stimulus, but also to address long-term challenges, such as de-carbonization, and preparing for unforeseen events in the future (Andrijevic et al. 2020).

This paper aims to expand the literature on what has driven the collapse in private investment, focusing particularly on the potential detrimental impact of both private and public debt. Myers (1977) was the first to identify the so-called debt overhang hypothesis, which generally pertains to the negative impact of excessive corporate debt on corporate investment. When deciding whether to finance new investments with debt, a firm's equity-holders consider that any increase in the firm's value must be shared with the firm's creditors. The smaller the benefits that go to the equity-holders because of this, the less attractive that investment is (Occhino 2010). On the other side of this incentive channel, there are also potential benefits as firms might take advantage of debt in terms of tax advantages. Without any disadvantages to counteract this benefit, firms should fund themselves exclusively through debt. However, this never occurs due to substantial risks associated with very high levels of debt financing such as increasing the probability of default or the debt overhang effect. Apart from this incentive channel, there are other mechanisms through which high corporate debt might be an impediment to investment. High debt levels usually translate into a higher risk perception of creditors (Merton 1974), which results in an increasing debtors' risk premium and cost of funding. The rising cost of capital might culminate in a lower number of projects, for which the expected return is higher than the cost of funding. Due to this decrease in profitable investment opportunities, companies will invest less. Additionally, the ensuing higher debt servicing costs for heavily indebted companies will simply leave less funds available for corporate investment (Maki 2002).

Corporate debt dynamics are strictly interconnected with household debt dynamics. Deleveraging in the corporate sector usually results in reduced investment and 
increased savings. Increased savings imply reduced wage costs, which affects household behavior (Bricongne and Mordonu 2017). Rising household debt also has the potential to destabilize an economy and impede private investment. Highly leveraged households are considered vulnerable to interest rate shocks: if their borrowing cost increases, they will invest less than households with limited leverage. More specifically, households that consider themselves excessively indebted will try to deleverage by reducing housing investment ${ }^{4}$ and consumption, which might result in decreased demand for companies' products. This effect is particularly pronounced in countries that are characterized by a large share of adjustable rotate mortgages, such as Greece, Italy or Spain (Albertazzi et al. 2019). Corporations will internalize this behavior and will not invest in additional production capacity. Should the deleveraging process fail and highly indebted households default on their mortgage en masse, banks that lent money to them might get into trouble. Even for sustainable borrowers, this would result in reducing credit, which in turn has an impact on investment (Aiyar et al. 2017).

Private investment could also be affected by high levels of public debt through a variety of channels (Traum and Yang 2015; Fatás et al. 2019). If the pool of loanable funds is limited, the public and private sector will compete for scarce resources when they tap financial markets. As the government increases its borrowing, it leaves less funds available for the private sector. This then pushes up borrowing costs for the private sector, which result in lower private investment. Additionally, high levels of public debt can cast doubts on the fiscal sustainability of a specific country. Households and companies might subsequently consume and invest less in anticipation of future tax increases (Barro 1996). The private sector generally considers public debt to be an indicator of economic uncertainty (Ahlborn and Schweickert 2018): if sovereign debt goes up, the economic outlook deteriorates and, particularly in a future mired in economic uncertainty, the incentive to invest will be lower.

In the paper, we study whether the EU suffers from a debt overhang, in which high debt results in low private investment by exploiting a panel of $28 \mathrm{EU}$ countries between 1995 and 2016. We also control for the occurrence of external shocks that might have caused debt to increase and private investment to decrease. Next, we study the role of credit conditions on the interaction between debt and private investment as the presence of financial frictions and credit rationing could strengthen a potential debt overhang effect. We explore the role of the financial channel further by examining whether a debt overhang effect is alleviated when financial institutions receive a bailout. Finally, we examine whether a debt overhang effect could be mitigated when countries are financially more open. This paper adds to the existing literature by: taking into account both public and private debt as potential drivers of declining private investment, focusing on the entire EU, and tackling the issue of endogeneity by using a GMM model to exploit the instrumental variable approach based on the linear GMM estimator of Arellano and Bond (1991).

The paper proceeds as follows. In Section 2, we review the literature. In Section 3 we describe the data. Section 4 contains the econometric approach. Section 5 discusses the main results, provides a number of robustness checks and adds several extensions. Section 6 concludes.

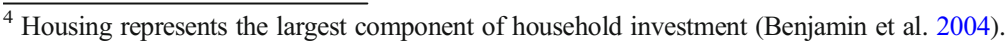




\section{Literature Review}

This section provides an overview of the relevant literature pertaining to the debt overhang hypothesis in Europe. First, we discuss those papers that analyze the link between corporate debt and corporate investment, and then examine the research on the potential negative effects of high levels of household debt. Finally, we report studies that focus on the potential relationship between high levels of public debt and low levels of private investment.

Only a relatively limited number of studies empirically analyze the extent to which high corporate debt impacts corporate investment decisions, keeping in mind that this mechanism was identified in 1977. These studies mostly focus on one country or on a small group of countries. Kalemli-Ozcan et al. (2019) find a negative link between corporate indebtedness and investment. This had already been prevalent before the GFC, and became even more apparent during that crisis. Similarly, Lawless et al. (2015) show that outstanding debt in Ireland impacts a broad array of firm performance indicators, such as investment and employment. Aivaziana et al. (2005) establish that high levels of debt are negatively related to investment in Canada, and that this effect is particularly strong for companies with low growth opportunities. Focusing on five peripheral euro area countries, Gebauer et al. (2018) find a non-linearity (a leverage ratio of $80-85 \%$ ) after which debt exerts a negative impact on investment. ${ }^{5}$ Studying the potential implications of debt overhang following the COVID-19 pandemic, Demmou et al. (2021) show that an increase in the debt-to-total-assets ratio of around 7 percentage points. This is comparable to their accounting model predictions and implies a fall in the ratio of investments to fixed assets by around 2 percentage points.

The negative effect of high levels of household debt has only recently been studied, generally with regard to its impact on household expenditure and subsequently on economic growth. Mian and Sufi (2015) argue persuasively that the GFC, as well as the slow recovery from it, was caused by a substantial run-up in household debt, followed by a significantly large reduction in household spending. Similarly, Brown and Lane (2011) find that mortgage debt, which is the largest portion of household debt, had a significant adverse impact on household consumption and investment in Emerging Europe during the GFC. In addition, Dynan et al. (2012), using household-level data, find that highly leveraged households cut back more on spending than less severely leveraged households during the GFC in the United States. Moreover, Intartaglia et al. (2017) show that although household debt can be expansionary in developing countries, it is generally contractionary in developed economies. Almost no research has been done on the negative impact of household debt on private investment in general and household investment in particular.

Although the literature on whether elevated levels of public debt lead to a decrease in private investment is rather limited, ${ }^{6}$ the empirical evidence does point in that

\footnotetext{
${ }_{5}^{5}$ Other studies providing empirical evidence on non-linear effects of (corporate) debt on private investment are Jäger (2003) and Goretti and Souto (2013). However, as expressed in the literature studying debt threshold effects on output growth, the presence of debt thresholds and of a non-monotone relationship between debt and growth does not seem to be robust to small changes in data coverage and empirical techniques (Cecchetti et al. 2011; Panizza and Presbitero 2013; Chudik et al. 2017; Liu and Lyu 2021).

${ }^{6}$ The public debt overhang hypothesis has been tested mainly for developing economies and generally with regard to the potential negative effect of debt on economic growth (Sen et al. 2007).
} 
direction. Woo and Kumar (2015) studied 38 advanced and emerging economies between 1970 and 2007 and showed that, on average, a 10\% increase in initial debt is associated with a decline of domestic investment by about $0.4 \%$ of GDP (with a larger impact in emerging economies). In Turkey, Chhibber et al. (1988) find that high levels of debt slowed down private investment due to an increase in the real interest rate, as domestic borrowing mainly financed large budget deficits. By contrast, Checherita-Westphal and Rother (2012) find a non-linear impact of debt on growth but they do not identify a direct impact of debt on private investment. Huang et al. (2016) discovered that between 2006 and 2013, local public debt issuance in China crowded out investment by private manufacturing firms through tightening their funding constraints. Follow-up research by Huang et al. (2018), using industry-level regressions, show a negative correlation between public debt and corporate investment, which is particularly strong for companies that need more external borrowing.

In summary, the debt overhang literature mostly looks at the impact of high corporate debt on firms' investment decisions. The paper takes a wider perspective and analyzes how debt levels in both the public and the private sectors (excluding financial institutions ${ }^{7}$ ) impact the propensity of households and firms to invest. As such, we add to the limited pool of literature on the potential crowding out of private investment by high levels of public debt. We do this by studying whether elevated levels of public debt rather than private debt caused the decline in private investment, which has been observed since 2007. The studies that analyzed the impact of public debt on private investment have focused on a single country. The advantage of singlecountry studies is that they often employ household-level data and yield insights for national policymakers (Vanlaer et al. 2019). However, from an EU policy perspective it is important to gain a clear understanding of the drivers of private investment across EU countries and of the role public debt plays in private GFCF. If EU policymakers wish to counter a reduction in private investment, and the consequent impact on economic output and social welfare, a key requirement is to clearly understand the determinants of private GFCF. To the best of our knowledge, no research has yet been done on the potential detrimental effect of high levels of both sovereign and private debt on total private investment across the EU. Our analysis provides timely and relevant insights for both policymakers, managing the economic fall-out from COVID-19, and academics studying the interplay between debt and private investment. This is particularly relevant given the unprecedented increase in public debt as a result of the COVID-19 related crisis as well as the importance of catalyzing private investment to kickstart the postpandemic economic recovery.

\section{Data Description}

Our variable of interest is private investment, which is defined as gross fixed capital formation for the private sector at current prices. As is standard in the literature, we

\footnotetext{
${ }^{7}$ Including the financial sector into this analysis would lead to double counting of several debt instruments, as financial institutions often lend to each other and some debt is rebundled in financial assets. For an overview of papers that do focus on excessive indebtedness in the financial sector, see Acharya et al. (2012) and Philippon and Schnabl (2013).
} 
consider this variable as a percentage of GDP to overcome differences in country welfare levels (Cordella et al. 2004; Checherita-Westphal and Rother 2012). As proxies of debt overhang, we consider firm, household and public debt. Firm debt is defined as the stock of liabilities non-financial corporations hold and household debt as the stock of liabilities of households and non-profit institutions serving households, both computed as a percentage of GDP. Public debt refers to the outstanding consolidated general government gross debt at nominal value at the end of the year as a percentage of GDP.

We follow the existing literature for the selection of additional determinants of private investment spending. Public investment as a percentage of GDP is taken into account because of its potential complementarity or substitutability (ChecheritaWestphal and Rother 2012). On the one hand, public investment in infrastructure (e.g. in roads) could crowd in private investment, hence acting as a complement to private GFCF (Erden and Holcombe 2005). On the other hand, public investment could also exert a negative impact on private investment when the private sector alters its investment plans in anticipation of higher taxes due to increased public expenditure, or when government spending drives up borrowing costs by competing with the private sector for scarce funds (Apergis 2000).

The one-year-ahead GDP growth forecast, collected from the IMF's World Economic Outlook reports released in October of each year, is considered as a proxy for expected demand (Bussiere et al. 2015). Forecasts of output growth play an important role in establishing current changes in corporate investments, as firms do not only include information on current aggregate demand in their investment decision making process, but also assessments of future demand.

Following Checherita-Westphal and Rother (2012) and Cordella et al. (2004), we consider how openness to international trade, measured by the summation of export and import divided by GDP, might play a role in private GFCF. Openness to trade could stimulate investment by encouraging competition in domestic and international markets, and generating higher returns on investment through economies of scale (Kim et al. 2013). Additionally, through the implementation of free trade agreements, countries have been able to attract greater flows of foreign direct investment (FDI) whose effect on private investment might be twofold (Liargovas and Skandalis 2012). On one hand, it can boost private investment by offering new investment opportunities for domestic companies through the provision of machinery and technology that cannot be sourced locally or through introducing new industries to the host country (Lipsey 2004; Sun 1998). On the other hand, FDI can crowd out private investment if domestic and foreign companies have to compete for scarce resources, or if foreign companies have a technological or managerial advantage (Jansen 1995; Noorzoy 1980).

Of course, the cost of funding an investment influences the decision to invest for both firms and households. To capture this, we employ the sovereign long-term borrowing rate (the long-term bond yield), which can also be considered as a proxy for the cost of funding for private companies. ${ }^{8}$ Since the sovereign is perceived as the most creditworthy borrower in an economy, its bond yields act as a 'floor' below which

\footnotetext{
${ }^{8} \mathrm{We}$ used the long-term bond yield instead of the lending rate to cover a larger time span and to not significantly reduce the sample size of our analysis. Both rates move together in most countries and in most periods as shown in Appendix 2
} 
private sector borrowing costs cannot fall. Consequently, higher borrowing rates for the sovereign also increase the cost of funding for private companies. Increased funding costs, in turn, result in a lower amount of investment that will be undertaken (Hambur and La Cava 2018).

We also consider the dependency ratio, measured as the ratio of dependents (people under 15 or over 64 years) to the working-age population (those aged 15-64). In a world with perfect capital mobility, capital (and hence investment) should flow from ageing countries to younger and growing countries with lots of investment opportunities, and thus higher investment returns (Hadjimichael et al. 1996). Moreover, a rising dependency ratio implies a reduction in output per capita and, consequently, declining investment, given the reduction in aggregate output and the lower labor-capital ratio.

Finally, following the existing literature, we also control for the potential crowdingin or -out effect that public spending can produce over private investment (Laopodis 2001; Kim and Nguyen 2020). Therefore, we control for the residual part of public expenditure, once public investment is excluded (Gali 1994, Fatás and Mihov 2001). Constituting a combination of discretionary spending and automatic stabilizers, this measure captures the effect of the fiscal policy response to a fluctuation in economic activity (Cottarelli and Fedelino 2010). A fiscal stimulus for the economy could indeed result in higher private investment and larger public debt.

Appendix 3 provides a description of the variables used in our analysis. Appendix 4 displays descriptive statistics for each variable for the period under consideration. Private GFCF averages $18.35 \%$, but is subject to a substantial degree of variation. Private investment reached its peak in Romania in 1998 at $31.74 \%$, whilst its trough was $7.64 \%$ in Greece in 2015. The changes in firm debt are even more striking. Nonfinancial corporate debt averaged $77.15 \%$, whereas Lithuania's firm debt level was only $24.5 \%$ in 1998 compared to Luxemburg's with over $249.6 \%$ in 2007 . The same holds true for household debt. The average household indebtedness in our sample is $53.92 \%$, but reaches a trough of 5.7\% in Slovakia in 2002 and a peak of $142.5 \%$ in Denmark in 2009. Public debt shows a similar dispersion. It averages $59.72 \%$ in our sample, but dropped as low as 3.66\% in Estonia in 2007 and rose as high as $180.85 \%$ in Greece in 2016. A correlation matrix is presented in Appendix 6.9

\section{Methodology}

To test empirically the debt overhang effect hypothesis, we wanted to estimate the following equation, which builds on Checherita-Westphal and Rother (2012):

$$
\begin{aligned}
\text { Private investment }_{i t}= & \beta_{1} \text { Household debt }_{i t-1}+\beta_{2} \text { Firm debt }_{i t-1} \\
& +\beta_{3} \text { Public debt }_{i t-1}+\beta_{4} \text { GDP forecast }{ }_{i t} \\
& +\sum_{c=1}^{7} \gamma_{c}\left(\text { Controls }_{i t-1}^{c}+v_{t}+\varepsilon_{i t}\right.
\end{aligned}
$$

\footnotetext{
${ }^{9}$ We have also tested whether the cross correlations change substantially if we exclude one of the debt variables, which is not the case.
} 
for $\mathrm{i}=1, \ldots, 28 \mathrm{EU}$ countries and $\mathrm{t}=1995, \ldots, 2016$. Private investment is the private gross fixed capital formation-to-GDP ratio. Household debt, Firm debt and Public debt are considered as a percentage of GDP. GDP forecast is the one-year-ahead GDP growth forecast produced by the IMF. Controls is a set of control variables that includes the public investment-to-GDP ratio, the long-term nominal interest rate, the degree of trade openness, the foreign direct investment-to-GDP ratio, the dependency ratio, and the residual government expenditure-to-GDP ratio. $\varepsilon_{i t}$ is the observationspecific error and $v_{t}$ the year fixed effects that capture factors that vary over time, but affect all countries.

All explanatory variables used in Eq. 1 except for the GDP forecast are lagged by one period. This allows us to take two things into account: investment decisions in year $t$ are generally based on the information available in year $t-1$, and to mitigate the simultaneous determination bias between private investment and other macroeconomic variables (Checherita-Westphal and Rother 2012; Picarelli et al. 2019). ${ }^{10}$ Two econometric challenges may arise from estimating Eq. 1. The first is how to capture the strong persistence of private investment, which is often observed over time (see Fig. 1 and Appendix 1). The second is the potential reverse causality, which is not fully mitigated through the lagged relation introduced in the equation. To deal with the first challenge, we decided to add the lagged value of our dependent variable among the regressors, which by definition gives rise to the so-called "dynamic panel bias" (Nickell 1981). Given its correlation with the units' fixed effects, this addition might attribute predictive power to the lagged dependent variable that actually belongs to the units' fixed effect. To tackle this problem and the potential endogeneity of other regressors, we use the difference GMM estimator developed by Arellano and Bond (1991). This approach deals with the aforementioned endogeneity in two steps. It first applies the first difference transformation, which removes the fixed effects at the cost of introducing correlation between $\Delta y_{i, t-1}$ and $\Delta \varepsilon_{i t}$, and then it exploits the standard Generalized Method of Moments procedure (Roodman 2009). An advantage of the Arellano-Bond estimation is that it is based on instruments taken from within the dataset, making it possible to use lags of the untransformed variables as instruments. However, this might come at the expense of producing an overfitting of endogenous variables when the set of instruments that are used is large. In this regard, we follow the approach suggested by Roodman (2009) and use a collapsed set of instruments. Finally, to evaluate the consistency of the difference GMM estimator, we test the validity of our internal instruments and the serial correlation of the error term. In the results below, standard errors are clustered at the country level, which makes them asymptotically robust to both heteroskedasticity and autocorrelation.

\section{Empirical Results}

The following section presents our main empirical findings. We start by discussing the results for our baseline specification, after which we perform a number of robustness

\footnotetext{
$\overline{10}$ The delay between when an investment decision is approved and when it is actually implemented should be taken into account.
} 
checks. Subsequently, we enrich our initial analysis by testing several hypotheses that could further explain these findings.

\subsection{Baseline Specification}

We find evidence to support the debt overhang hypothesis in the EU. This is evident from Table 1, which shows the regression results for our baseline specification. Of note is that the debt overhang effect only works through the public debt channel; neither firm nor household debt is a significant determinant of private investment.

According to these results, a 1 percentage increase in public debt produces an average reduction in private investment of 0.14 percentage points. Alternatively, given the levels of private investment prevalent in 2016, a 10 percentage point decrease in public debt in the EU would result in an increase in private GFCF of $€ 18.32$ billion. By looking at the long-run elasticity of private investment to public debt, a permanent increase of public debt by $1 \%$ will eventually lead to a $0.23 \%$ reduction in private investment. $^{11}$

As expected, the past value to a significant extent determines the current level of private investment, which shows a substantial degree of persistence in private investment. In addition, our results indicate that public investment, anticipated demand, and FDI seem to be important determinants of private investment. ${ }^{12}$

\subsection{Robustness Checks}

Although the results presented in Section 5.1 indicate that, from 1995 to 2016, high levels of public debt is associated with low levels of private investment, external shocks might have caused both sovereign debt to increase and private investment to decrease. A common shock has the potential to simultaneously affect private investment and its determinants, and therefore the link between both. Hence, we consider the effects of a global (worldwide) shock and of a local (EU-centered) shock on the negative impact of public debt on private investment.

To take a global shock into account, we included the CBOE Volatility Index (VIX) in our baseline specification (Erce 2019), which is generally regarded as a barometer of volatility and uncertainty in financial markets. For the local shock, we rely on the European financial crises database of the European Systemic Risk Board, which identifies financial crises by combining a quantitative approach with expert judgement from national and European authorities (Lo Duca et al. 2017). As an alternative, we construct a variable for the historical volatility of stock returns as the square root of the mean squared daily equity returns during the year (Bussiere et al. 2015; Vu 2015). This measure can be considered as another proxy for a "local" shock or uncertainty.

Finally, we study whether the link between private investment and public debt differs during periods of rising public debt compared to periods of declining public debt, and whether it holds once institutional variables are taken into account. Higher

\footnotetext{
${ }^{11}$ We also tested for the debt overhang effect by looking only at the euro area (EA) and we find a negative and significant effect of public debt on private investment with a coefficient of -0.124 , which is in line with the negative effect of public debt on private investment for the entire EU.

${ }^{12}$ Results remain qualitatively similar when we exclude each country in the sample one by one. We also show results by using POLS in Appendix 5.
} 
Table 1 Regression results for the EU countries: baseline specification

\begin{tabular}{|c|c|}
\hline & BASELINE \\
\hline Private investment $t_{t-1}$ & $0.385^{\mathrm{c}}(0.139)$ \\
\hline Firm debt $t_{t-1}$ & $0.022(0.025)$ \\
\hline Household debt $t_{t-1}$ & $-0.057(0.045)$ \\
\hline Public debt $t_{t-1}$ & $-0.141^{\mathrm{c}}(0.039)$ \\
\hline Public investment $t_{t-1}$ & $-0.631^{\mathrm{a}}(0.355)$ \\
\hline Borrowing rates $(L T)_{t-1}$ & $0.024(0.185)$ \\
\hline$G D P$ foreacast $_{t}$ & $0.551^{\mathrm{b}}(0.244)$ \\
\hline Trade openness $t_{t-1}$ & $-0.032(1.762)$ \\
\hline$F D I_{t-1}$ & $0.011^{\mathrm{a}}(0.006)$ \\
\hline Dependency ratio $_{t-1}$ & $-0.015(0.167)$ \\
\hline Residual public expenditures $_{t-1}$ & $-0.074(0.080)$ \\
\hline Observations & 449 \\
\hline Year FE & Yes \\
\hline $\operatorname{AR}(1)(p$ value $)$ & 0.001 \\
\hline $\operatorname{AR}(2)(p$ value $)$ & 0.189 \\
\hline Number of instruments & 59 \\
\hline Difference-in-Sargan ( $p$ value) & 0.410 \\
\hline
\end{tabular}

Dependent variable: Private investment. Heteroskedasticity-robust standard errors clustered at country level are in parentheses. ${ }^{\mathrm{a}},{ }^{\mathrm{b}}$, and ${ }^{\mathrm{c}}$ indicate significance at the $10 \%, 5 \%$, and $1 \%$ levels, respectively. AR(1) and $\mathrm{AR}(2)$ report the serial correlation test for the error terms. Difference-in-Sargan reports the exogeneity tests for the instruments used in the regression. Each control variable is considered as potentially endogenous except for trade openness, dependency ratio, and residual public expenditures ratio which we consider as predetermined

levels of private investment in countries with a better institutional framework could partly explain the Lucas paradox. The paradox observes that capital does not flow from developed countries to developing countries despite the fact that developing countries have lower levels of capital per worker (Lucas 1990), and this could influence the way public debt affects private investment. More specifically, we first add a dummy variable assuming a value of 1 when the stock of public debt is increasing and 0 otherwise, and then include a variable that measures the change in the corruption level in each country. ${ }^{13}$ We interact public debt with all the additional control variables discussed above to see whether the public debt overhang effect differs for different values of the regressors taken into account, and to identify potential non-linearities. We report the results in Table 2 below.

The results confirm our initial findings. Even when controlling for several additional factors that might have altered the relation between private investment and public debt, we still find evidence of a public debt overhang effect, ranging between -0.07 and 0.177. ${ }^{14}$ Moreover, the debt overhang effect seems to be stronger during a global shock

\footnotetext{
${ }^{13}$ Given its feature of being a slow-moving variable, we consider the change in the level of corruption to reduce potential autocorrelation this variable might add.

${ }^{14}$ The lower bound of this range has to be interpreted with caution, given the smaller sample due to the short data on corruption and to the autocorrelation still partly presents in the error term.
} 


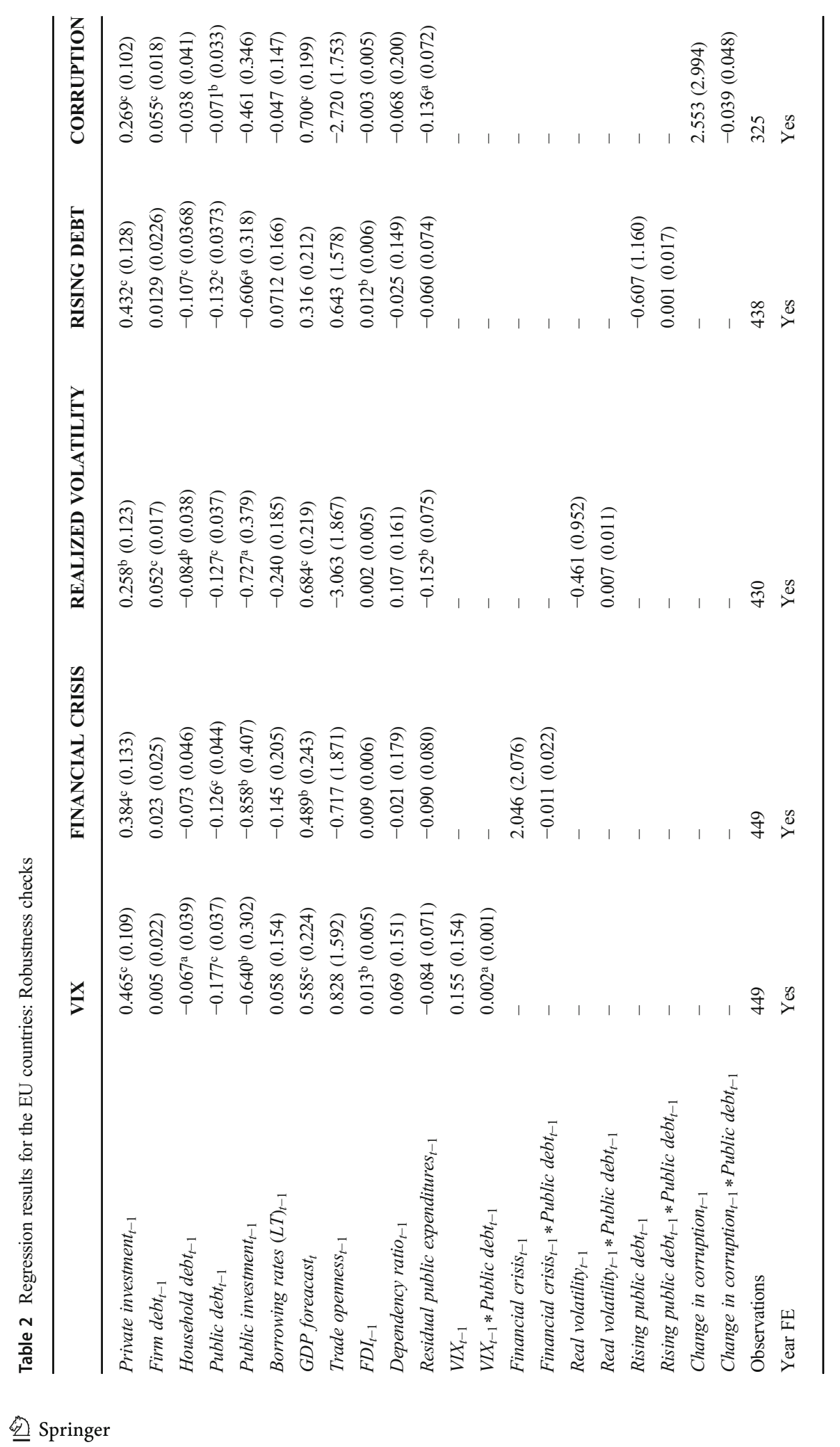




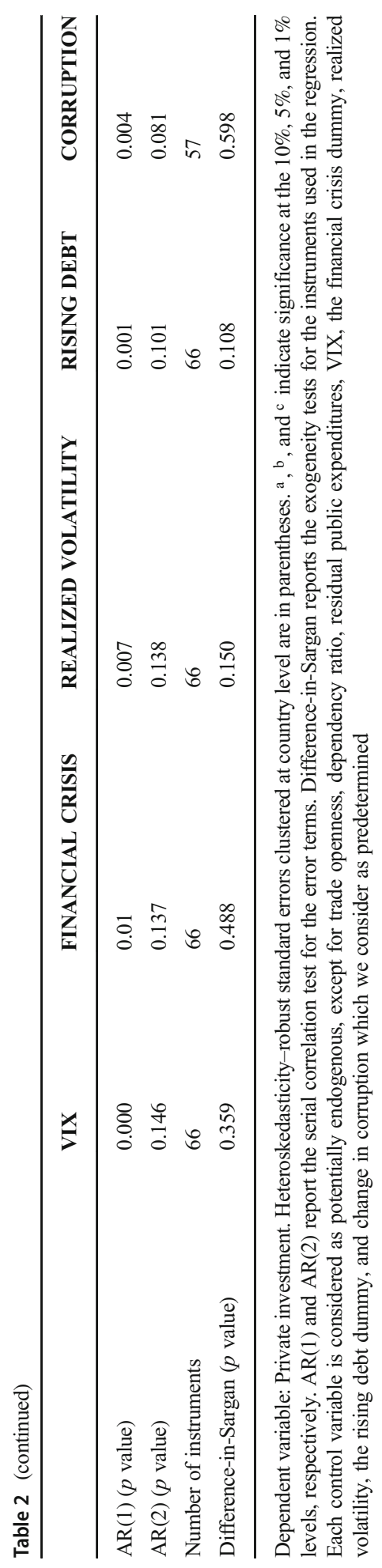


rather than when a local shock occurs. This could be explained as follows. Since the VIX co-moves with the global financial cycle, it captures events that have a quasiuniversal remit (Nier et al. 2014). Thus, an increase in the VIX represents a tightening of global financial conditions for nearly every sovereign and company, consequently reinforcing the debt overhang effect. By contrast, the local shock focuses on countryspecific events with impacts and consequences of these events varying from country to country. As a result, the debt overhang effect is not as strong as a global shock, which affects almost every country and every firm simultaneously.

Interestingly, when looking at the interaction term, we notice that the debt overhang effect is actually mitigated when global uncertainty rises. As described in the related literature, a number of factors determine the relationship between investment and uncertainty, and these factors can either be positive or negative (Bloom 2014). According to the largest body of literature, which focuses on "real options", the sign of this relationship should be negative (Bernanke 1983). In times of high uncertainty, the option value for delaying investment is also high for firms, which means they become cautious about investment decisions. However, the real option theory does not always hold. If market competition is high or speed is of the essence (e.g. when firms are scrambling to patent a new idea or launch a new product), investment will be higher even in uncertain times. The "growth options" (Segal et al. 2015) illustrate that uncertainty can also increase investment if it increases the size of the potential reward, as was the case during the dot-com bubble. An increase in agents' precautionary saving or in optimistic/risk seeking agents (the Oi-Hartman-Abel effect) would produce the same result (Malmendier and Tate 2005; Bansal and Yaron 2004; Oi 1961; Hartman 1972; Abel 1983).

Our results also indicate that the debt overhang effect is not stronger in periods of rising public debt, and that the negative effect of public debt on private investment is still present when institutional quality is considered. We also find tentative evidence of a negative effect household debt exerts over private investment, which however does not hold in every regression. Nevertheless, even in those specifications where household debt negatively impacts private investment, the negative effect of public debt is still larger. The other results are in line with what we found using our baseline specification.

\subsection{The Financial Channel}

In this section, we investigate the role of the financial channel on the interaction between sovereign debt and private investment. The crowding-out effect of private GFCF by public debt could be more pronounced if government debt tightens the credit constraints for private firms as a result of the presence of financial frictions and credit rationing (Broner et al. 2014).

\subsubsection{The Financial Channel: The Role of Credit Conditions}

A first important element to consider is to what extent the debt overhang effect depends on credit conditions. As credit from the banking sector represents an important source of funding for investment, financial sector conditions need to be taken into account when studying how the credit channel might influence the interaction between debt and private investment. Both the quantity and the price of credit could play a role here. Regarding quantities, we consider the credit-to-GDP gap, which captures the build-up 
of excessive credit compared to its backward-looking long-term trend, and the change in the NPL ratios. A supply of credit below its long-term trend would signal a contraction in credit with banks less willing or able to provide additional credit to the economy. Consequently, this slowdown in supplying credit would result in a constraint for investment funding.

Similarly, a drag on the supply of credit might come from increasing levels of NPL ratios in the banking sector. The GFC showed that banks free of balance-sheet rigidities were more likely than those featuring high volumes of NPL ratios to continue lending throughout the cycle, and thus supported the economic recovery. Banks experiencing an increasing share of NPLs on their balance sheets are at risk of suffering credit losses and, consequently, a reduction in bank equity (Fredriksson and Frykström 2019). As a result, they restrict their supply of credit, which could lead to reduced private investment. ${ }^{15}$ For the reasons just explained, the credit-to-GDP gap and the change in NPL ratios could also yield information regarding financial stress in a specific country. Additionally, we build a dummy variable, which assumes a value of 1 when the change in NPL ratios is negative and 0 otherwise, to control what effect a decrease in nonperforming assets produces on credit supply and in turn on private investment.

What price aspects are concerned, we consider the role of monetary policy easing and a measure proxying for the cost of capital. The extraordinary expansionary monetary policies adopted in the wake of the GFC resulted in unprecedentedly low interest rates for borrowers, and in corporate bond spreads close to their historical lowest level in several market segments (De Santis et al. 2018; Li et al. 2019). To explore whether expansionary monetary policies eased the debt overhang effect by lowering the cost of cost of financing for the private sector, we control for the balance sheet size of central banks. As an additional control, we aim to capture the same effect by looking at the real cost of capital, which is defined as follows (Lee and Rabanal 2010; Lewis et al. 2014):

$$
\text { Real cost of capital }:(i-\pi+\delta) *\left(\frac{G F C F \text { deflator }}{G D P \text { deflator }}\right)
$$

where $i$ is the long-term government bond yield, $\pi$ is the annual growth rate of the GDP deflator, $\delta$ is the fixed capital depreciation rate, and the ratio $\left(\frac{G F C F \text { deflator }}{G D P \text { deflator }}\right)$ corresponds to the relative price of investment goods.

We then interact public debt with these five additional control variables and report the results in Table 3.

Even if limited data availability significantly reduces both the time dimension and the countries included in the sample, the results confirm our previous findings. ${ }^{16}$ The public debt overhang effect ranges between -0.04 and -0.113 and it does not change when interacted with the financial explanatory variables described above. ${ }^{17}$ Therefore,

\footnotetext{
$\overline{15}$ The reduction in credit can occur via multiple channels, such as limiting the supply of credit, raising its price or tightening credit standards.

${ }^{16}$ Given that data on NPL ratios and on credit demand come from the ECB, the sample includes only euro area countries in those cases.

${ }^{17}$ Results coming from the regression that uses the change in NPL ratios should be interpreted with caution given the weak exogeneity of instruments used.
} 


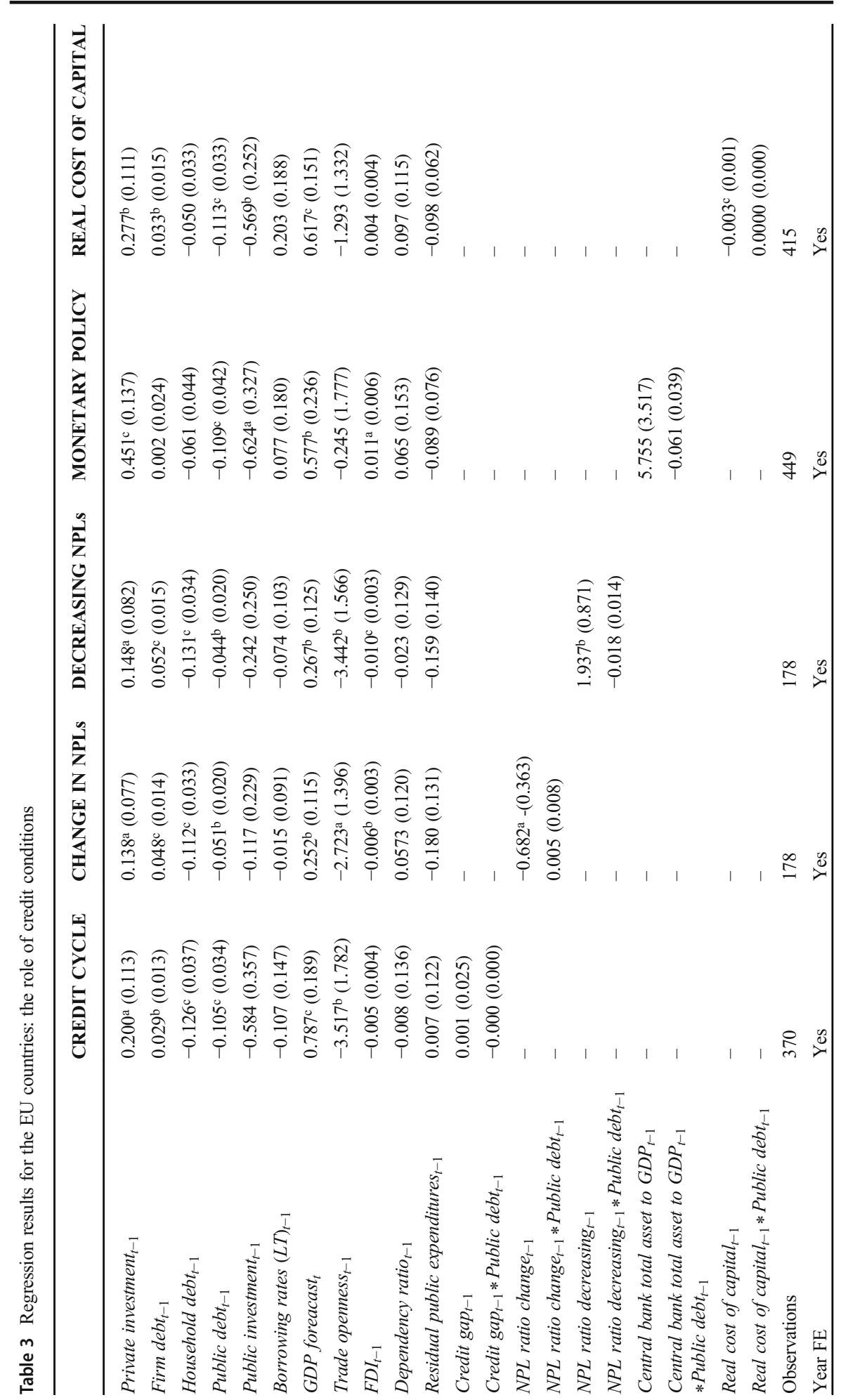




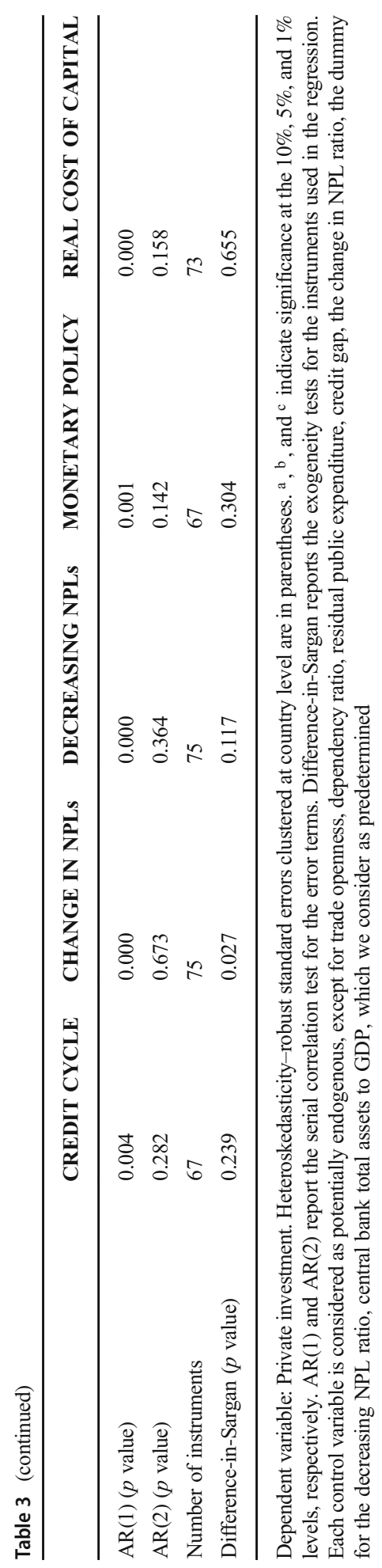


while we observe that a positive change in the NPL ratios weighs on private investment (vice versa for a decrease in the NPL ratios), we find no evidence that public debt tightens the credit constraints for private firms and worsens the debt overhang. What the cost of funding is concerned, we do not find evidence that expansionary monetary policies alleviated the public debt overhang effect by reducing the cost of funding. Similarly, although we find that a higher real cost of capital exerts a negative effect on private investment, it does not worsen the debt overhang effect. Interestingly, we find tentative evidence of a larger private debt overhang effect, which comes from household debt. This is evident once credit supply aspects, such as the credit-to-GDP gap and the NPL ratio, are taken into account. This effect vanishes once proxies for the cost of funding are considered. Evidence on firm debt remains unclear.

\subsubsection{The Financial Channel: The Role of Bailout}

In this section, we study the effect of government interventions to support financial institutions on the interaction between sovereign debt and private investment. Bailouts could alleviate financial distress for the selected banks, which in turn might boost their provision of credit, consequently impacting private GFCF (Giannetti and Simonov 2013). To attain this goal, bailouts should be structured and implemented in an efficient way (Bhattacharya and Nyborg 2013). If not, they might result in under-investment (Philippon and Schnabl 2013), adverse selection (Gorton and Huang 2004) or risk shifting (Acharya et al. 2011; Acharya et al. 2014; De Bruyckere et al. 2013; Ejsing and Lemke 2011; Erce 2019). We consider the bailout data reported by the European Commission and interact them with public debt. Given that bailout data for some countries are reported in local currency, we convert the data by using the exchange rates from AMECO. Moreover, to make the values comparable across countries, we divide the amount of the bailout by the GDP of each country. Results are reported in Table 4.

The results are in line with our previous findings. Public debt still has a significantly negative impact on private investment, while private debt does not. As the coefficient of the interaction term is not significant, the inclusion of Bailout in our specification does not materially alter how public debt affects private investment. Hence, the negative effect of public debt on private investment does not seem to be mitigated if countries bail out their banking sectors. While bailouts are beneficial for the financial sector because they can alleviate a distortion in credit provision; they come at a cost. The government can finance the bailouts either through issuing additional debt or by increasing taxes, and both channels have the potential to increase the debt overhang effect. Higher taxes reduce the incentive to invest as profits will be lower. Bailouts financed by new debt issuances simply imply a risk transfer from banks to the sovereign, as the government's financial support translates into a higher debt level (Gaballo and Zetlin-Jones 2016). As a result, while financial distress in the banking sector is relieved through the bailout, the default risk might be transferred to the public sector. As Acharya et al. (2014) showed, announcements of financial sector bailouts in euro area countries, which occurred between 2007 and 2010, resulted in an immediate widening of sovereign CDS spreads and narrowing of bank CDS spreads. ${ }^{18}$

\footnotetext{
${ }^{18}$ When the Irish government announced the guarantee of all deposits of its six biggest banks on September 2008, the CDS of Irish banks fell from 400 basis points to 150, whereas Ireland's CDS increased sharply (Acharya et al. 2014).
} 
Table 4 Regression results for the EU countries: the role of bailout

\begin{tabular}{|c|c|c|}
\hline & BAILOUT DUMMY & BAILOUT SIZE \\
\hline Private investment $t_{t-1}$ & $0.489^{\mathrm{c}}(0.149)$ & $0.350^{\mathrm{b}}(0.138)$ \\
\hline Firm debt $t_{t-1}$ & $0.002(0.026)$ & $0.012(0.024)$ \\
\hline Household debt $t_{t-1}$ & $-0.054(0.050)$ & $-0.051(0.043)$ \\
\hline Public debt $t_{t-1}$ & $-0.117^{b}(0.045)$ & $-0.111^{\mathrm{c}}(0.036)$ \\
\hline Public investment $t_{t-1}$ & $-0.917^{\mathrm{b}}(0.448)$ & $-0.723^{\mathrm{b}}(0.352)$ \\
\hline Borrowing rates $(L T)_{t-1}$ & $0.008(0.250)$ & $0.068(0.205)$ \\
\hline$G D P$ foreacast $_{t}$ & $0.721^{\mathrm{b}}(0.311)$ & $0.447^{a}(0.247)$ \\
\hline Trade openness $t_{t-1}$ & $-0.796(2.073)$ & $-0.855(1.805)$ \\
\hline$F D I_{t-1}$ & $0.010(0.007)$ & $0.006(0.006)$ \\
\hline Dependency ratio $t_{t-1}$ & $0.025(0.192)$ & $-0.087(0.171)$ \\
\hline Residual public expenditures $_{t-1}$ & $-0.110(0.096)$ & $-0.106(0.084)$ \\
\hline Bailout dummy $t_{t-1}$ & $3.771^{\mathrm{a}}(2.129)$ & - \\
\hline Bailout dummy $_{t-1} *$ Public debt $_{t-1}$ & $-0.036(0.024)$ & - \\
\hline Bailout to $G D P_{t-1}$ & - & $0.101(1.159)$ \\
\hline Bailout to $G D P_{t-1} *$ Public debt $t_{t-1}$ & - & $-0.004(0.011)$ \\
\hline Observations & 449 & 449 \\
\hline Year FE & YES & YES \\
\hline $\operatorname{AR}(1)$ ( $p$ value $)$ & 0.001 & 0.009 \\
\hline $\operatorname{AR}(2)(p$ value $)$ & 0.358 & 0.363 \\
\hline Number of instruments & 65 & 65 \\
\hline Difference-in-Sargan ( $p$ value) & 0.695 & 0.225 \\
\hline
\end{tabular}

Dependent variable: Private investment. Heteroskedasticity-robust standard errors clustered at country level are in parentheses. ${ }^{\mathrm{a}}, \mathrm{b}$, and ${ }^{\mathrm{c}}$ indicate significance at the $10 \%, 5 \%$, and $1 \%$ levels, respectively. AR(1) and $\mathrm{AR}(2)$ report the serial correlation test for the error terms. Difference-in-Sargan reports the exogeneity tests for the instruments used in the regression. Each control variable is considered as potentially endogenous except for trade openness, dependency ratio, residual public expenditures, the bailout dummy, and bailout size, which we consider as predetermined

\subsubsection{The Financial Channel: The Role of Financial Openness}

Another important aspect to consider is whether the financial openness of countries could mitigate a debt overhang effect. The more a country is financially open, the more capital flows to fund additional investment opportunities. The debt overhang effect could then be mitigated and private investment could be larger as a result. However, to date there is no consensus in the literature on the benefits of financial openness (Bussiere and Fratzscher 2008). On the one hand, according to standard economic theory based on models of competitive and efficient markets, increased financial openness can boost private investment and thus economic development. Banks and capital markets are indeed able to channel a larger pool of financial resources towards investments and other productive activities that augment an economy's productive capacity (Estrada et al. 2015). Financial openness and international capital flows can also foster a 
more efficient allocation of resources and raise productivity growth (Kose et al. 2009). On the other hand, more access to foreign capital could encourage excessive borrowing, expose countries to capital flight - especially during crisis times - and result in an economic contraction (Ghosh et al. 2020). To take the financial openness of countries into account, we consider the Chinn-Ito index, which measures a country's degree of capital account openness (Chinn and Ito 2006). Additionally, we construct a dummy that assumes a value of 1 in case of positive changes in the Chinn-Ito index, and 0 otherwise, to capture positive changes in the degree of financial openness.

When considering financial openness, the role of the sovereign debt investor base cannot be neglected. Between 1995 and 2007, financial integration in the euro area led to reducing the share of resident investors in public debt holdings and subsequently to a diversified investor base. With the eruption of the GFC, instead, the trend reversed. Foreign investors fled and domestic banks increased their exposure toward the respective sovereign. While larger domestic holdings of public debt are usually associated with higher long-term yields, an increase in demand by foreign investors produces the opposite effect (Arslanalp and Poghosyan 2016) ${ }^{19}$ However, foreign investors are also considered to be more volatile holders of public debt. Thus, in times of stress, they are generally quick to sell their bond holdings of distressed sovereigns, resulting in higher bond yields, increased refinancing costs for the country, and potentially sudden stops. Hence, in an adverse scenario where sovereign debt stress rises, large domestic holdings of public debt have the possibility to act as a cushion to these rapid outflows of debt, constituting a more stable source of funding. ${ }^{20}$ The link between public debt and investor base thus has important implications in terms of financial stability. To consider such a link, we introduce external debt into our analysis, which represents the share of public debt held by nonresidents as a percentage of the stock of outstanding public debt. We interact the variables described above with public debt and we present results in Table 5 .

While results confirm the existence of the debt overhang effect, we find evidence that financial openness could mitigate the negative effect exerted by public debt over private investment in European countries. ${ }^{21}$ Increased capital mobility somewhat relaxes potential constraints on domestic investment and the credit constraints for private investment that are the result of excessive public debt. A potential explanation could be that attracting foreign capital compensates a contraction in the domestic pool of financial resources due to higher public debt levels. We also find that positive changes in the Chinn-Ito index, which indicates increases in a country's financial openness, do act as a boost for private investment. By looking at external debt, we find evidence pointing in a similar direction. Countries featuring a larger share of public debt held

\footnotetext{
${ }^{19}$ Through the end of 2012, for example, foreign outflows resulted in upward pressure in the peripheral euro area countries.

${ }^{20}$ There are however risks associated with a large share of public debt held domestically as it creates a dangerous link between financial institutions and governments that can magnify negative shocks (Gibson et al. 2017).

${ }^{21}$ Results should however be interpreted with caution given the weak exogeneity of the instruments used.
} 
Table 5 Regression results for the EU countries: financial openness

\begin{tabular}{|c|c|c|c|}
\hline & CHINN-ITO & $\begin{array}{l}\text { Change in the } \\
\text { CHINN-ITO }\end{array}$ & External debt \\
\hline Private investment $t_{t-1}$ & $0.331^{\mathrm{c}}(0.128)$ & $0.392^{\mathrm{c}}(0.115)$ & $0.380^{\mathrm{c}}(0.130)$ \\
\hline Firm debt $_{t-1}$ & $0.031(0.027)$ & $0.003(0.022)$ & $0.0242(0.0323)$ \\
\hline Household debt $t_{t-1}$ & $-0.044(0.050)$ & $-0.049(0.046)$ & $0.00401(0.0575)$ \\
\hline Public debt $t_{t-1}$ & $-0.091^{\mathrm{b}}(0.046)$ & $-0.102^{\mathrm{c}}(0.038)$ & $-0.322^{\mathrm{c}}(0.0832)$ \\
\hline Public investment $_{t-1}$ & $-0.600^{\mathrm{a}}(0.321)$ & $-0.877^{\mathrm{c}}(0.295)$ & $-0.917^{\mathrm{b}}(0.386)$ \\
\hline Borrowing rates $(L T)_{t-1}$ & $-0.063(0.172)$ & $-0.318^{\mathrm{a}}(0.180)$ & $-0.275(0.256)$ \\
\hline$G D P$ foreacast $_{t}$ & $0.277(0.247)$ & $0.359(0.221)$ & $0.338(0.344)$ \\
\hline Trade openness $s_{t-1}$ & $-4.405^{b}(1.895)$ & $-3.234^{\mathrm{a}}(1.911)$ & $-3.301(2.505)$ \\
\hline$F D I_{t-1}$ & $-0.011(0.007)$ & $-0.007(0.007)$ & $-0.0138^{\mathrm{a}}(0.00816)$ \\
\hline Dependency ratio $_{t-1}$ & $-0.097(0.230)$ & $0.103(0.194)$ & $-0.297(0.245)$ \\
\hline Residual public expenditures $_{t-1}$ & $-0.108(0.082)$ & $0.111(0.186)$ & $0.279(0.190)$ \\
\hline Chinn Ito $_{t-1}$ & $-1.186(0.942)$ & - & - \\
\hline Chinn Ito $_{t-1} *$ Public debt $t_{t-1}$ & $0.030^{\mathrm{a}}(0.016)$ & - & - \\
\hline Chinn Ito positive chg $_{t-1}$ & - & $3.392^{\mathrm{b}}(1.712)$ & - \\
\hline Chinn Ito positive chg $_{t-1} *$ Public debt $t_{t-1}$ & - & $-0.041(0.028)$ & - \\
\hline External debt $t_{t-1}$ & - & - & $-0.157^{\mathrm{a}}(0.081)$ \\
\hline Public debt $_{t-1} *$ External debt $_{t-1}$ & - & - & $0.004^{\mathrm{c}}(0.001)$ \\
\hline Observations & 436 & 425 & 382 \\
\hline Year FE & YES & YES & YES \\
\hline $\mathrm{AR}(1)(p$ value $)$ & 0.005 & 0.000281 & 0.00226 \\
\hline $\operatorname{AR}(2)(p$ value $)$ & 0.141 & 0.313 & 0.912 \\
\hline Number of instruments & 66 & 66 & 66 \\
\hline Difference-in-Sargan ( $p$ value) & 0.046 & 0.044 & 0.151 \\
\hline
\end{tabular}

Dependent variable: Private investment. Heteroskedasticity-robust standard errors clustered at country level are in parentheses. ${ }^{\mathrm{a}}, \mathrm{b}$, and $\mathrm{c}$ indicate significance at the $10 \%, 5 \%$, and $1 \%$ levels, respectively. AR(1) and $\mathrm{AR}(2)$ report the serial correlation test for the error terms. Difference-in-Sargan reports the exogeneity tests for the instruments used in the regression. Each control variable is considered as potentially endogenous except for trade openness, dependency ratio, residual public expenditure, Chinn-Ito, the dummy capturing positive changes in the Chinn-Ito, and external debt, which we consider as predetermined

abroad are associated with a higher level of private investment. As pointed out by Arslanalp and Poghosyan (2016) this might be explained by the fact that a large amount of public debt held abroad results in lower yields, which in turns leads to more private investment.

\section{Conclusions}

Given the unprecedented rise in public debt generated by the COVID-19 related crisis, recent academic and policy debates have focused on its potential 
detrimental effect on the economy. Our paper tackles this research question by studying the impact of both public and private debt on private investment, which is one of the most important GDP components that will be essential to kick start the economic recovery. Our analysis provides timely and relevant insights for European policymakers managing the economic fall-out from COVID-19. If an increase in debt results in decreased private GFCF, this has an impact on the long-term productive potential of the EU and, consequently, on the living standards of its citizens. If the aim is to ensure a sustained increase in prosperity, it is crucial to acknowledge - and deal with - this debt overhang effect.

The literature on the link between debt and private investment has generally focused on the corporate debt overhang (Gebauer et al. 2018), used micro data, and has not included the entire EU. Research on the negative interaction between public debt and private investment is rather limited. We add to the limited literature by using data across the entire EU for the period between 1995 and 2016, and assessing whether public or private debt has been the most important contributor to the decline in private investment.

While we find scant evidence for the private debt overhang hypothesis, we do find that an increase in public debt results in decreased private investment. A rise in general government debt of 1 percentage point brings about a reduction in private investment of 0.14 percentage points. These results hold after controlling for a number of factors that might have caused public debt to increase and private investment to decrease. We identify two potential mechanisms in place. Firstly, if sovereign debt increases, corporations and households might expect future taxes to rise as well, so they cut back on investment. Secondly, the private sector potentially views the level of public debt as an indicator of economic uncertainty. If public debt increases, the economic outlook is perceived as less benign and the incentive to invest in an uncertain future becomes lower.

Next, we study the role of credit conditions on the interaction between debt and private investment as the presence of financial frictions and credit rationing could strengthen a potential debt overhang effect. Indeed, credit from the banking sector represents an important source of funding for investment and due to the introduction of financial frictions and credit rationing, government debt could tighten the credit constraints for private firms. We consider a host of different variables to capture these credit conditions, but find no evidence that higher public debt levels worsen the debt overhang effect by tightening the credit constraints for firms.

We further investigate the role of shocks and the financial channel through examining the impact of a strained financial sector on the interaction between sovereign debt and private investment. We do this by studying whether reducing stress in the financial system through government bailouts of the banking 
sector has an impact on the debt overhang effect. Interestingly, we find no evidence that bank bailouts, at least in our sample, have played a significant role in mitigating the negative impact of public debt on private GFCF. The financial openness of a country, however, does mitigate the public debt overhang effect. This might suggest that attracting foreign capital compensates for a contraction in the domestic pool of financial resources due to higher public debt levels. However, these results should be interpreted with caution given the relatively weak exogeneity of the instruments used. To overcome this problem, future research might focus on a broad set of indicators of financial openness to assess whether the relation between private investment and public debt observed in this paper still hold.

\section{Appendix 1}

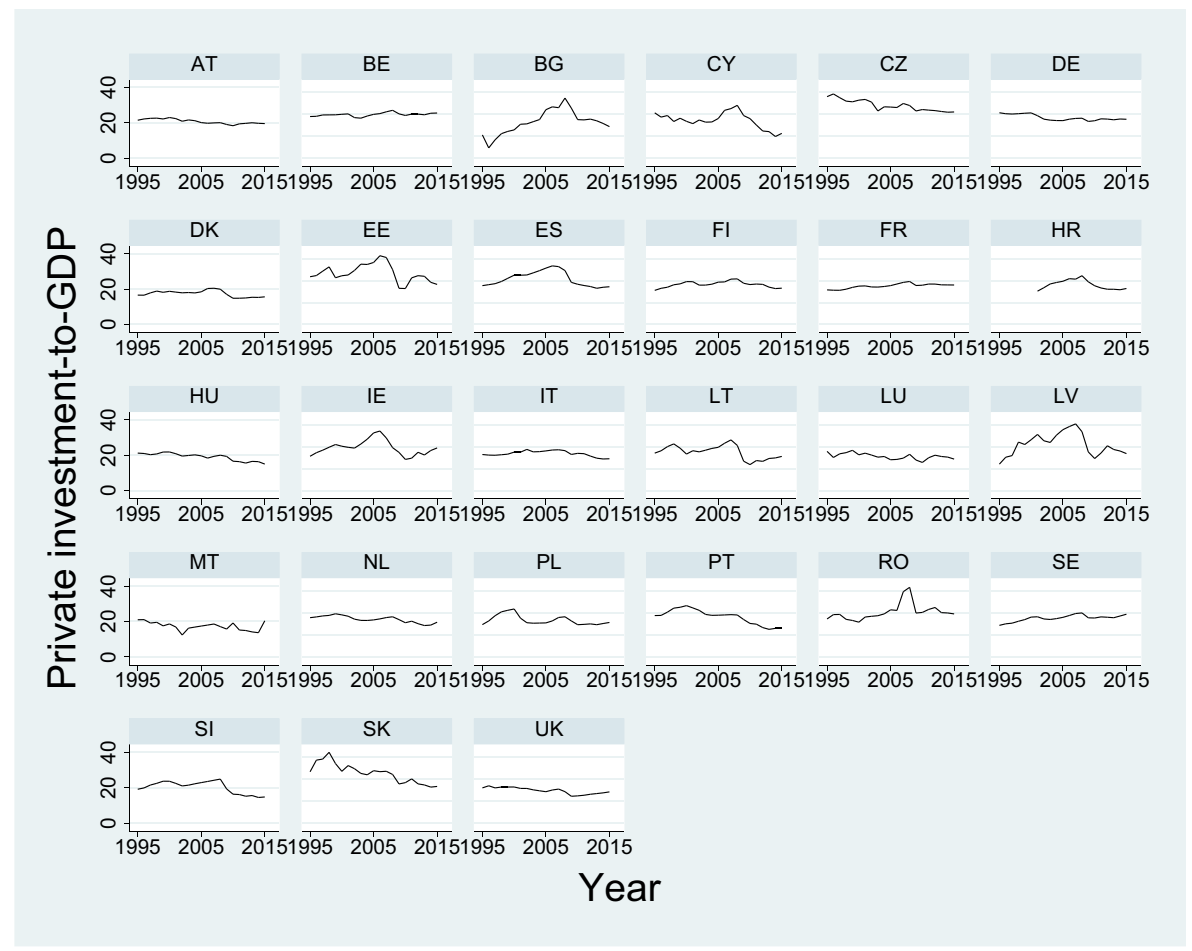

Fig. 2 Private investment-to-GDP ratios for EU28, 1995-2016. Source: AMECO 


\section{Appendix 2}

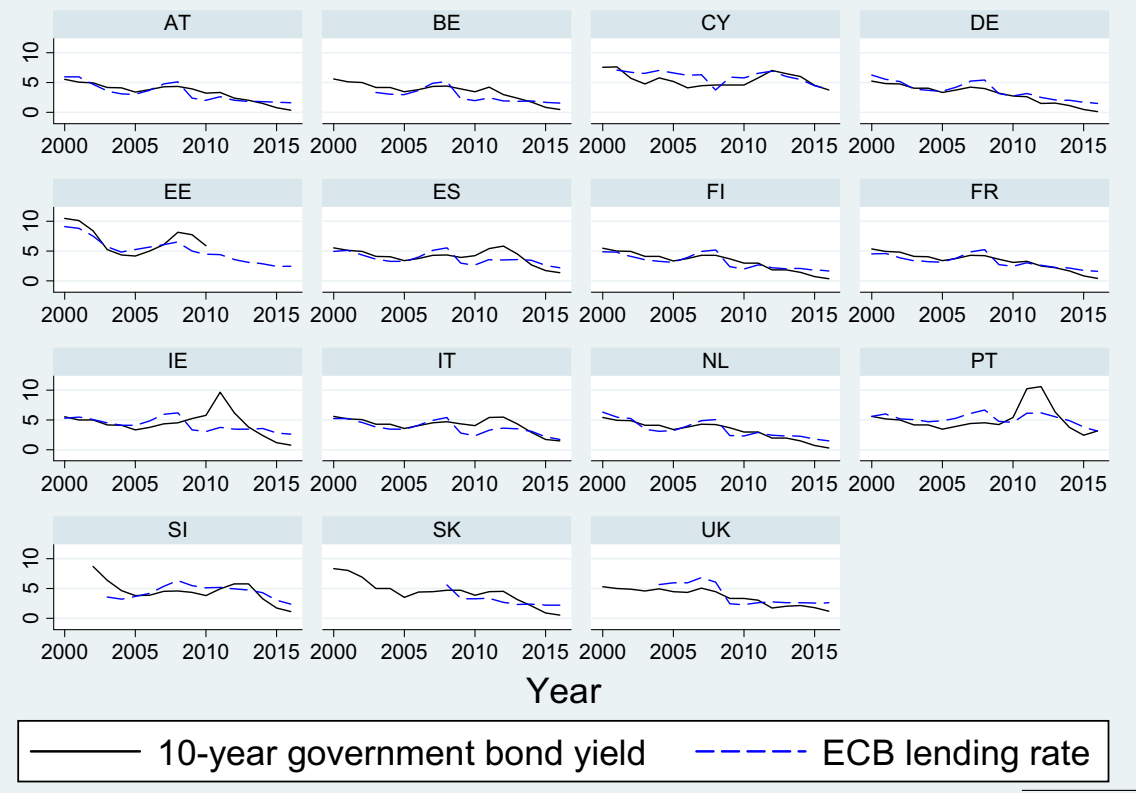

Fig. 3 Evolution of the 10-year government bond yield and the ECB lending rate, 2000-2016. Source: $\mathrm{AMECO}$ and $\mathrm{ECB}$

\section{Appendix 3}

Table 6 Variables description

\begin{tabular}{lll}
\hline Variable name & Description & Source \\
\hline Private investment & $\begin{array}{l}\text { Private gross fixed capital formation by } \\
\text { households and non-financial corporations, } \\
\text { as a percentage of GDP }\end{array}$ & AMECO \\
Firm debt & $\begin{array}{l}\text { Non-financial corporate debt as a percentage of GDP } \\
\text { Debt of households and non-profit institutions }\end{array}$ & Eurostat \\
Household debt & Eerving households, as percentage of GDP \\
Public debt & $\begin{array}{l}\text { Consolidated general government gross debt, as } \\
\text { a percentage of GDP }\end{array}$ & Eurostat \\
Public investment & General government gross fixed capital formation & Eurostat \\
Borrowing rate (LT) & as a percentage of GDP & \\
GDP forecast & $\begin{array}{l}\text { Sovereign long-term nominal interest rate } \\
\text { One-year-ahead IMF World Economic Outlook } \\
\text { Grade openness }\end{array}$ & AMF growth forecast (fall)
\end{tabular}


Table 6 (continued)

\begin{tabular}{|c|c|c|}
\hline Variable name & Description & Source \\
\hline Foreign direct investment & $\begin{array}{l}\text { Investment made by a firm or individual in one } \\
\text { country into business interests located in } \\
\text { another country (acquiring at least } 10 \% \text { of the } \\
\text { voting power), as a percentage of GDP }\end{array}$ & Eurostat \\
\hline Dependency ratio & $\begin{array}{l}\text { Ratio of dependents (people younger than } 15 \text { or } \\
\text { older than } 64 \text { ) to the working-age population } \\
\text { (those aged 15-64) }\end{array}$ & World Bank \\
\hline Residual public expenditure & $\begin{array}{l}\text { General government expenditure as a percentage } \\
\text { of GDP computed excluding public investment }\end{array}$ & AMECO \\
\hline VIX & $\begin{array}{l}\text { Volatility index computed from the S\&P } 500 \\
\text { stock index option prices }\end{array}$ & Haver Analytics \\
\hline Financial crisis dummy & $\begin{array}{l}\text { Crises are identified by combining a quantitative } \\
\text { approach with expert judgement from national } \\
\text { and European authorities }\end{array}$ & ESRB \\
\hline Realized volatility & $\begin{array}{l}\text { Square root of the mean squared daily equity } \\
\text { returns during the year. }\end{array}$ & $\begin{array}{l}\text { Authors' } \\
\text { computation }\end{array}$ \\
\hline Corruption & $\begin{array}{l}\text { Reflects perceptions of the extent to which public } \\
\text { power is exercised for private gain, including } \\
\text { both petty and grand forms of corruption, as } \\
\text { well as "capture" of the state by elites and } \\
\text { private interests. }\end{array}$ & World Bank \\
\hline Domestic credit gap & $\begin{array}{l}\text { The credit-to-GDP gap is defined as the difference } \\
\text { between the credit-to-GDP ratio and its } \\
\text { backward-looking long-term trend (deviation) in } \\
\text { percentage points. }\end{array}$ & ECB \\
\hline NPLs & Ratio of non-performing loans to total loans & ECB \\
\hline Central bank's total assets & Central Bank: Financial assets to GDP & Eurostat \\
\hline Real cost of capital & $\begin{array}{l}\text { The real cost of capital is a function of the relative } \\
\text { purchase price of investment goods, the long-term } \\
\text { government bond yield, inflation and the capital } \\
\text { depreciation rate. }\end{array}$ & $\begin{array}{l}\text { AMECO, Authors' } \\
\text { calculations }\end{array}$ \\
\hline Bailout & $\begin{array}{l}\text { Capital injections recorded as deficit-increasing } \\
\text { (capital transfer) }\end{array}$ & $\begin{array}{l}\text { European } \\
\text { Commission }\end{array}$ \\
\hline Chinn-Ito index & $\begin{array}{l}\text { Index measuring a country's degree of capital } \\
\text { account openness }\end{array}$ & $\begin{array}{l}\text { Haver } \\
\text { Analytics }\end{array}$ \\
\hline External debt & $\begin{array}{l}\text { General government debt held by non-residents, } \\
\text { as a percentage of total outstanding debt }\end{array}$ & ECB \\
\hline
\end{tabular}




\section{Appendix 4}

Table 7 Descriptive statistics

\begin{tabular}{|c|c|c|c|c|c|c|}
\hline Variable & Unit & No. Obs. & Mean & Std. Dev. & Min. & Max. \\
\hline \multicolumn{7}{|l|}{ Dependent variable } \\
\hline Private investment & $\%$ of GDP & 449 & 18.35 & 3.58 & 7.64 & 31.74 \\
\hline \multicolumn{7}{|l|}{ Variables of interest } \\
\hline Firm debt & $\%$ of GDP & 449 & 77.15 & 42.36 & 24.5 & 249.6 \\
\hline Household debt & $\%$ of GDP & 449 & 53.92 & 29.84 & 5.7 & 142.5 \\
\hline Public debt & $\%$ of GDP & 449 & 59.72 & 31.54 & 3.66 & 180.85 \\
\hline \multicolumn{7}{|l|}{ Control variables } \\
\hline Public investment & $\%$ of GDP & 422 & 3.74 & 1.05 & 1.64 & 7.26 \\
\hline Borrowing rate (LT) & $\%$ & 448 & 4.40 & 2.27 & .09 & 22.5 \\
\hline GDP forecast & $\%$ change & 449 & 2.31 & 1.71 & -4 & 9 \\
\hline Trade openness & $\%$ of GDP & 449 & 1.11 & .64 & .39 & 4.10 \\
\hline Foreign direct investment & $\%$ of GDP & 421 & 11.14 & 39.24 & -58.98 & 451.72 \\
\hline Dependency ratio & $\%$ & 422 & 48.65 & 4.12 & 38.10 & 60.27 \\
\hline Residual public expenditure & $\%$ of GDP & 422 & 36.84 & 6.63 & 21.26 & 50.00 \\
\hline \multicolumn{7}{|l|}{ Robustness checks } \\
\hline VIX & Index & 422 & 20.68 & 6.29 & 12.78 & 32.65 \\
\hline Realized volatility & basis points & 430 & 1.32 & 0.60 & 0.42 & 4.48 \\
\hline Corruption change & Change in the index & 325 & -0.01 & 0.09 & -0.29 & 0.38 \\
\hline \multicolumn{7}{|l|}{ Extensions } \\
\hline Domestic credit gap & $\%$ of GDP & 370 & .59 & 18.38 & -54.99 & 78.76 \\
\hline NPLs change & $\%$ change & 177 & 0.09 & 0.46 & -0.62 & 4.10 \\
\hline Central bank's total assets & $\%$ of GDP & 422 & 0.35 & 0.51 & 0.01 & 3.25 \\
\hline User cost of capital & $\%$ & 388 & 859.71 & 398.08 & -139.11 & 3675.65 \\
\hline Bailout size & $\%$ of GDP & 422 & 0.13 & 0.89 & 0 & 12.26 \\
\hline Chinn-Ito index & Index & 436 & 2.01 & 0.75 & -1.22 & 2.33 \\
\hline External debt & $\%$ of government debt & 382 & 48.93 & 16.90 & 6.19 & 82.30 \\
\hline
\end{tabular}




\section{Appendix 5}

Table 8 Baseline regression results: POLS and fixed effects

\begin{tabular}{|c|c|c|c|c|}
\hline & $\begin{array}{l}\text { Private } \\
\text { investment }\end{array}$ & $\begin{array}{l}\text { Private } \\
\text { investment }\end{array}$ & $\begin{array}{l}\text { Private } \\
\text { investment }\end{array}$ & $\begin{array}{l}\text { Private } \\
\text { investment }\end{array}$ \\
\hline Firm debt $t_{t-1}$ & $0.002(0.006)$ & $0.005(0.006)$ & $0.014^{\mathrm{a}}(0.008)$ & $0.020^{\mathrm{c}}(0.007)$ \\
\hline Household debt $t_{t-1}$ & $-0.017^{b}(0.008)$ & $-0.020^{\mathrm{c}}(0.007)$ & $-0.021^{\mathrm{a}}(0.012)$ & $-0.022(0.016)$ \\
\hline Public debt $t_{t-1}$ & $-0.028^{c}(0.007)$ & $-0.014^{\mathrm{b}}(0.007)$ & $-0.119^{\mathrm{c}}(0.010)$ & $-0.068^{\mathrm{c}}(0.011)$ \\
\hline Public investment $_{t-1}$ & $0.818^{\mathrm{c}}(0.156)$ & $0.664^{\mathrm{c}}(0.153)$ & $0.189(0.155)$ & $0.208(0.149)$ \\
\hline Borrowing rates $(L T)_{t-1}$ & $-0.032(0.067)$ & $-0.078(0.074)$ & $-0.123^{\mathrm{a}}(0.065)$ & $-0.314^{\mathrm{c}}(0.075)$ \\
\hline$G D P$ foreacast $_{t}$ & $0.921^{\mathrm{c}}(0.106)$ & $0.931^{\mathrm{c}}(0.124)$ & $0.732^{\mathrm{c}}(0.086)$ & $0.638^{\mathrm{c}}(0.093)$ \\
\hline Trade openness $s_{t-1}$ & $-0.260(0.346)$ & $-0.316(0.347)$ & $0.129(0.782)$ & $0.318(0.813)$ \\
\hline$F D I_{t-1}$ & $0.004(0.005)$ & $-0.004(0.004)$ & $0.009^{\mathrm{c}}(0.003)$ & $0.002(0.003)$ \\
\hline Dependency ratio $_{t-1}$ & $0.299^{\mathrm{c}}(0.032)$ & $0.205^{\mathrm{c}}(0.035)$ & $0.466^{\mathrm{c}}(0.044)$ & $0.403^{\mathrm{c}}(0.049)$ \\
\hline Residual public expenditures $_{t-1}$ & $0.034(0.031)$ & $0.046(0.030)$ & $0.107^{\mathrm{b}}(0.054)$ & $0.111^{\mathrm{a}}(0.057)$ \\
\hline Observations & 477 & 477 & 477 & 477 \\
\hline Year FE & No & Yes & No & Yes \\
\hline Country FE & No & No & Yes & Yes \\
\hline
\end{tabular}

Dependent variable: Private investment. Heteroskedasticity-robust standard errors clustered at country level are in parentheses. ${ }^{\mathrm{a}}, \mathrm{b}$, and $\mathrm{c}$ indicate significance at the $10 \%, 5 \%$, and $1 \%$ levels, respectively 


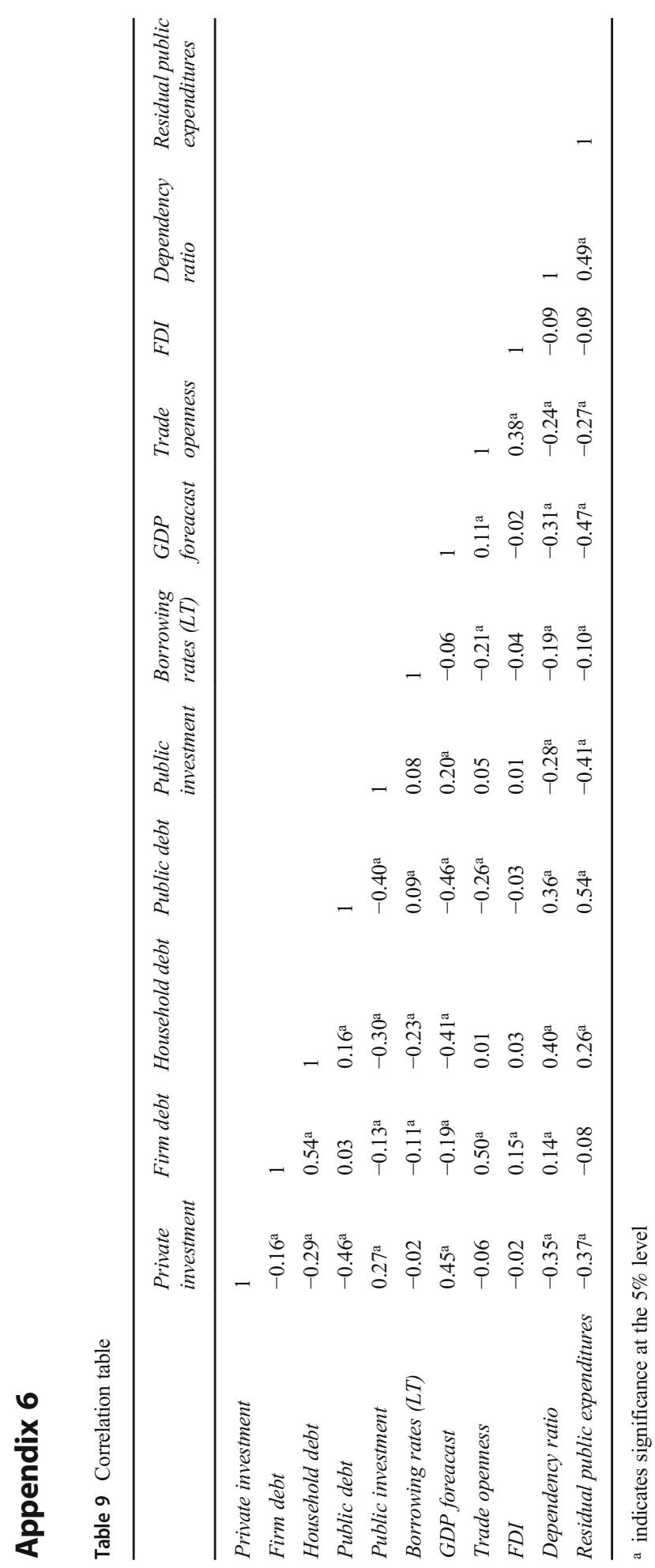


Acknowledgements We thank Samanta Bielen, Nicola Borri, Angela Capolongo, Alessandra Donini, Guido Traficante, Lorenzo Ricci, and two anonymous reviewers for their constructive comments on an earlier draft of this manuscript. Sylvia Baudet von Gersdorff provided excellent editorial support. The views expressed in this paper are solely the responsibility of the authors and should not be interpreted as representing the views of the European Stability Mechanism.

\section{References}

Abel AB (1983) Optimal investment under uncertainty. Am Econ Rev 73(1):228-233

Acharya VV, Drechsler I, Schnabl P (2012) A tale of two overhangs: the nexus of financial sector and sovereign credit risks. FSR Financial 51

Acharya VV, Drechsler I, Schnabl P (2014) A pyrrhic victory? Bank bailouts and sovereign credit risk. J Financ 69(6):2689-2739

Acharya VV, Shin HS, Yorulmazer T (2011) Crisis resolution and Bank liquidity. Rev Financ Stud 24(6): 2166-2205

Ahlborn M, Schweickert R (2018) Public debt and economic growth - economic systems matter. IEEP 15(2): $373-403$

Aiyar S, Bergthaler W, Garrido JM, Ilyina A, Kang K, Kovtun D, Moretti M (2017) A strategy for resolving Europe's problem loans. Eur Econ 1:87-95

Aivazian VA, Ge Y, \& Qiu J (2005) The impact of leverage on firm investment: Canadian evidence. J Corp Finance 11(1-2):277-291

Albertazzi, U, Fringuellotti, F, Ongena, S (2019) Fixed rate versus adjustable rate mortgages: Evidence from euro area banks. ECB Working Paper No. 2322

Andrijevic M, Schleussner CF, Gidden MJ, McCollum DL, Rogelj J (2020) COVID-19 recovery funds dwarf clean energy investment needs. Science 370(6514):298-300

Apergis N (2000) Public and private investments in Greece: complementary or substitute 'goods'? Bull Econ Res 52(3):225-234

Arellano M \& Bond S (1991) Some tests of specification for panel data: Monte Carlo evidence and an application to employment equations. Rev Econ Stud 58(2):277-297

Arslanalp S, Poghosyan T (2016) Foreign investor flows and sovereign bond yields in advanced economies. J Banking Financial Econ 2(6):45-67

Banerjee R, Hofmann B (2018) The rise of zombie firms: causes and consequences. BIS Quarterly Review September

Bansal R, Yaron A (2004) Risks for the long run: a potential resolution of asset pricing puzzles. J Financ 59(4):1481-1509

Barro RJ (1996) Reflections on Ricardian equivalence. NBER Working Paper No. w5502

Benjamin J, Chinloy P, Jud D (2004) Why do households concentrate their wealth in housing? J Real Estate Res 26(4):329-344

Bernanke BS (1983) Irreversibility, uncertainty, and cyclical investment. Q J Econ 98(1):85-106

Bhattacharya S, Nyborg KG (2013) Bank Bailout Menus. Rev Corporate Finance Stud 2(1):29-61

Bloom N (2014) Fluctuations in uncertainty. J Econ Perspect 28(2):153-176

Bricongne J, Coutinho L, Turrini A, Zeugner S (2020) Is private debt excessive? Open Econ Rev 31:471-512

Bricongne J-C, Mordonu A (2017) Interlinkages between household and corporate debt in advanced economies. Open Econ Rev 28:1029-1055

Broner F, Erce A, Martin A, Ventura J (2014) Sovereign debt markets in turbulent times: creditor discrimination and crowding-out effects. J Monet Econ 61(C):114-142

Brown M, Lane P (2011) Debt overhang in emerging Europe? The World Bank Policy Research Paper No. 5784

Bussiere, M, Ferrara, L, Milovich, J (2015) Explaining the recent slump in investment: the role of expected demand and uncertainty. Banque de France Working Paper No. 571

Bussiere M, Fratzscher M (2008) Financial openness and growth: short-run gain, long-run pain? Rev Int Econ 16(1):69-95

Cecchetti, S G, Mohanty, M S, Zampolli, F (2011) The Real Effects of Debt. BIS Working Paper No. 352

Checherita-Westphal C, Rother P (2012) The impact of high government debt on economic growth and its channels: an empirical investigation for the euro area. Eur Econ Rev 56(7):1392-1405 
Chhibber A, Van Wijnbergen S, Mundial B (1988) Public policy and private investment in Turkey. The World Bank Working Paper 120

Chinn MD, Ito H (2006) What matters for financial development? Capital controls, institutions, and interactions. J Dev Econ 81(1):163-192

Chudik A, Mohaddes K, Pesaran MH, Raissi M (2017) Is there a debt-threshold effect on output growth? Rev Econ Stat 99(1):135-150

Cordella T, Ricci LA, Ruiz-Arranz M (2004) Debt overhang or debt irrelevance? Revisiting the debt-growth link. IMF Working Paper 05/223

Cottarelli, M C, Fedelino, M A (2010) Automatic Stabilizers and the Size of Government: Correcting a Common Misunderstanding. IMF Working Paper 10/155

De Bruyckere V, Gerhardt M, Schepens G, Vennet RV (2013) Bank/sovereign risk spillovers in the European debt crisis. J Bank Financ 37(12):4793-4809

De Santis RA, Geis A, Juskaite A, Cruz LV (2018) The impact of the corporate sector purchase programme on corporate bond markets and the financing of euro area non-financial corporations. Econ Bull 3

Demmou, L, Franco, G, Calligaris, S, Dlugosch, D (2021) Liquidity shortfalls during the COVID-19 outbreak: assessment and policy responses, OECD Economics Department Working Papers No. 1647

Dynan K, Mian A, Pence KM (2012) Is a household debt overhang holding back consumption? Comments and discussion. Brookings Papers on Economic Activity 299

Ejsing J, Lemke W (2011) The Janus-headed salvation: sovereign and bank credit risk premia during 20082009. Econ Lett 110(1):28-31

Erce A (2019) Bank and sovereign risk pass-through: Evidence from the euro area. Int Finance 23(1):64-84

Erden L, Holcombe RG (2005) The effects of public investment on private investment in developing economies. Public Finance Rev 33(5):575-602

Estrada, G B, Park, D, Ramayandi, A (2015) Financial development, financial openness, and economic growth. Asian Development Bank Economics Working Paper Series 442

European Investment Bank (EIB) (2013) Investment and investment finance in Europe, p 2013

Fatás A, Ghosh A, Panizza U, Presbitero AF (2019) The motives to borrow. CEPR Discussion Paper No. 13735

Fatás A, Mihov I (2001) Government size and automatic stabilizers: international and intranational evidence. J Int Econ 55(1):3-28

Fredriksson O, Frykström N (2019) "Bad loans" and their effects on banks and financial stability, Economic Commentary Sveriges Riksbank

Gaballo G, Zetlin-Jones A (2016) Bailouts, moral hazard and banks' home bias for sovereign debt. J Monet Econ 81:70-85

Gali J (1994) Government size and macroeconomic stability. Eur Econ Rev 38(1):117-132

Gebauer S, Setzer R, Westphal A (2018) Corporate debt and investment: a firm level analysis for stressed euro area countries. J Int Money Financ 86:112-130

Ghosh AR, Kim JI, Qureshi MS (2020) What's in a name? That which we call capital controls. Econ Policy 35(101):147-208

Giannetti M, Simonov A (2013) On the real effects of bank bailouts: micro evidence from Japan. Am Econ J Macroecon 5(1):135-167

Gibson H, Hall S, Tavlas G (2017) Self-fulfilling dynamics: the interactions of sovereign spreads, sovereign ratings and bank ratings during the euro financial crisis. J Int Money Financ 73(B):371-385

Goretti, M, Souto, M (2013) Macro-financial implications of corporate (de-)leveraging in the euro area periphery. IMF Working Paper 13/154

Gorton G, Huang L (2004) Liquidity, efficiency, and Bank bailouts. Am Econ Rev 94(3):455-483

Hadjimichael MT, Nowak M, Sharer RL, Tahari A (1996) Adjustment for growth: the African experience. IMF Occasional Paper 143

Hambur J, La Cava G (2018) Do interest rates affect business investment? Evidence from Australian company-level data. Reserve Bank of Australia Research Discussion Paper RDP 2018-05

Hartman R (1972) The effects of Price and cost uncertainty on investment. J Econ Theory 5(2):258-266

Huang Y, Pagano M, Panizza U (2016) Public debt and private firm funding: evidence from Chinese cities CEPR Discussion papers no 11489

Huang Y, Panizza U, Varghese R (2018) Does public debt crowd out corporate investment? International evidence CEPR Discussion papers no. 12931

Intartaglia M, Antoniades A, Bhattacharyya S (2017) Unbundled debt and economic growth in developed and developing economies: an empirical analysis. World Econ 41(12):3345-3358

Jäger, A (2003) Corporate balance sheet restructuring and investment in the euro area. IMF Working Paper 03/ 117 
Jansen K (1995) The macroeconomic effects of direct foreign investment: the case of Thailand. World Dev 23(2):193-210

Kalemli-Ozcan S, Laeven L, Moreno D (2019) Debt overhang, rollover risk and investment in Europe. ECB Working Paper No. 2241

Khan MS, Reinhart CM (1990) Private investment and economic growth in developing countries. World Dev 18(1):19-27

Kim DH, Lin SC, Suen YB (2013) Investment, trade openness and foreign direct investment: social capability matters. Int Rev Econ Financ 26:56-69

Kim T, Nguyen QH (2020) The effect of public spending on private investment. Rev Finance 24(2):415-451

Kose MA, Prasad ES, Terrones ME (2009) Does openness to international financial flows raise productivity growth? J Int Money Financ 28(4):554-580

Krugman P, Mankiw NG (1994) Peddling prosperity: economic sense and nonsense in the age of diminishing expectations. J Econ Lit 33(4):1987-1988

Laopodis NT (2001) Effects of government spending on private investment. Appl Econ 33(12):1563-1577

Lawless M, O'Connell B, O’Toole C (2015) SME recovery following a financial crisis: does debt overhang matter? J Financ Stab 19:45-59

Lee J, Rabanal P (2010) Forecasting U.S. investment. IMF Working Paper 10/246

Lewis, C, Pain N, Strasky J, Menkyna F (2014) Investment Gaps after the Crisis, OECD Economics Department Working Papers No. 1168

Li F, Mercatanti A, Mäkinen T, Silvestrini A (2019) A regression discontinuity design for categorical ordered running variables with an application to central bank purchases of corporate bonds. Bank of Italy Temi di Discussione (working paper) No. 1213

Liargovas PG, Skandalis KS (2012) Foreign direct investment and trade openness: the case of developing economies. Soc Indic Res 106(2):323-331

Lipsey RE (2004) Home-and host-country effects of foreign direct investment. In: Baldwin RE, Winters A (eds) Challenges to globalization: analyzing the economics. University of Chicago Press, pp 333-382

Liu Z, Lyu J (2021) Public debt and economic growth: threshold effect and its influence factors. Appl Econ Lett 28(3):208-212

Lo Duca, M, Koban, A, Basten, M, Bengtsson, E, Klaus, B, Kusmierczyk, P, Lang, J H, Detken, C, Peltonen, T (2017) A new database for financial crises in European countries. ESRB Occasional Paper Series 194

Lucas RE (1990) Why doesn't capital flow from rich to poor countries? Am Econ Rev 80(2):92-96

Maki DM (2002) The growth of consumer credit and the household debt service burden. In: Durkin TA, Staten ME (eds) The impact of public policy on consumer credit. Springer, Boston, pp 43-68

Malmendier U, Tate G (2005) CEO overconfidence and corporate investment. J Financ 60(6):2661-2700

Merton RC (1974) On the pricing of corporate debt: the risk structure of interest rates. J Financ 29(2):449-470

Mian A, Sufi A (2015) House of debt: how they (and you) caused the great recession, and how we can prevent it from happening again. University of Chicago Press

Myers SC (1977) Determinants of corporate borrowing. J Financ Econ 5:147-175

Nickell SJ (1981) Biases in dynamic models with fixed effects. Econometrica 49(6):1417-1426

Nier E, Sedik TS, Mondino T (2014) Gross private capital flows to emerging markets: can the global financial cycle be tamed? IMF Working Paper 14/196

Noorzoy MS (1980) Flows of direct investment and their effects on US domestic investment. Econ Lett 5(4): 311-317

Occhino F (2010) Is debt overhang causing firms to underinvest? Economic Commentary, pp 2010-2007

Oi WY (1961) The desirability of Price instability under perfect competition. Econometrica 29(1):58-64

Panizza U, Presbitero AF (2013) Public debt and economic growth in advanced economies: a survey. Swiss J Econ Stat 149(2):175-204

Philippon T, Schnabl P (2013) Efficient recapitalization. J Financ 68(1):1-42

Picarelli M, Vanlaer W, Marneffe W (2019) Does public debt produce a crowding out effect for public investment in the EU? ESM Working Paper Series 36

Reinhart C, Rogoff K (2010) Growth in a time of debt. Am Econ Rev 100(2):573-578

Roodman D (2009) A note on the theme of too many instruments. Oxf Bull Econ Stat 71(1):135-158

Segal G, Shaliastovich I, Yaron A (2015) Good and bad uncertainty: macroeconomic and financial market implications. J Financ Econ 117(2):369-397

Sen S, Kasibhatla KM, Stewart DB (2007) Debt overhang and economic growth - the Asian and the Latin American experiences. Econ Syst 31(1):3-11

Sun H (1998) Macroeconomic impact of direct foreign investment in China: 1979-96. World Economy 21(5): 675-694

Traum N, Yang SCS (2015) When does government debt crowd out investment? J Appl Econ 30(1):24-45 
Vanlaer W, Bielen S, Marneffe W (2019) Consumer confidence and household saving behaviors: a crosscountry empirical analysis. Soc Indic Res 147(2):1-45

$\mathrm{Vu} N$ (2015) Stock market volatility and international business cycle dynamics: evidence from OECD economies. J Int Money Financ 50:1-15

Woo J, Kumar M (2015) Public debt and growth. Economica 82(328):705-739

Publisher's Note Springer Nature remains neutral with regard to jurisdictional claims in published maps and institutional affiliations. 